\title{
Luminescent Properties of a Polymeric Copper(I)-bromide Complex in a PMMA Film
}

Chika Nanzan, Yorimasa Takazawa, Mitsuaki Suzuki, Hiroyuki Teramae, and Tomomi Sakata*

Department of Chemistry, Faculty of Science, Josai University, 1-1 Keyakidai, Sakado, Saitama 350-0295, Japan

"E-mail: sakata@ josai.ac.jp, tel.: +81-49-271-8012.

The $\left[\mathrm{Cu}_{2} \mathrm{Br}_{2}(\mathrm{DIB})_{2}\left(\mathrm{PPh}_{2}\right)_{2}\right]_{\mathrm{n}}$ complex, obtained by the reaction between $\left[\mathrm{Cu}_{4} \mathrm{Br}_{4}\left(\mathrm{PPh}_{3}\right)_{4}\right]$ and 1,4-diisocyanobenzene (DIB), was found to have a bridged polymeric structure with a planar $\left\{\mathrm{Cu}_{2} \mathrm{Br}_{2}\right\}$ core. The compound exhibited bluish-green $\left(\lambda_{\max }=498 \mathrm{~nm}\right)$ and green $\left(\lambda_{\max }=515 \mathrm{~nm}\right)$ luminescence at 295 and $77 \mathrm{~K}$, respectively, corresponding to the emissions from XLCT (HE band) and (X+M)LCT (LE band), respectively. The dual emission, which is attributed to the luminescence from both bands, was observed at around $178 \mathrm{~K}$. The complex also displayed a change in luminescence color from bluish-green to yellow $\left(\lambda_{\max }=529 \mathrm{~nm}\right)$ upon applying external mechanical stimuli. The film containing $\left[\mathrm{Cu}_{2} \mathrm{Br}_{2}(\mathrm{DIB})_{2}\left(\mathrm{PPh}_{2}\right)_{2}\right]_{\mathrm{n}}$ was prepared by a cast method using polymethyl methacrylate as a binding agent. The rubbed part of the film turned yellow and the other parts maintained bluish-green luminescence. Restoration of the initial color was feasible by annealing, even in film state. 


\section{Introduction}

With increasing interest in post organic light-emitting diodes (OLEDs), copper(I)-containing stimuli-responsive complexes have attracted considerable attention due to their potential applications in photonic and sensing devices. ${ }^{1-19)}$ In particular, copper(I)-halide complexes can take multiple coordination forms, depending on the electronic and steric effects of the ligand, such as mono-, di-, tetranuclear, and bridged oligomer or polymer, resulting in diverse photophysical properties. For instance, copper(I)-iodide complexes are characterized by two emission bands derived from different excited states, whose relative intensity changes with temperature. ${ }^{20-25)}$ As a representative example, the dual phosphorescent emission from the cubane-type complex of $\left[\mathrm{Cu}_{4} \mathrm{I}_{4}(\mathrm{py})_{4}\right]$ (py = pyridine) originates from ${ }^{3} \mathrm{X} / \mathrm{MLCT}$ (triplet halogen- or metal-to-ligand charge transfer) and ${ }^{3} \mathrm{CC}$ (triplet cluster center) states, which correspond to emissions from high-energy (HE) and low-energy (LE) bands, respectively. ${ }^{26)}$ There are no reports in the literature on dual emission, except for complexes having cubane skeleton. A feasible explanation is that most complexes are not likely to have two bands simultaneously, or that they do not possess sufficient kinetic energy for surpassing the potential barrier between two bands in the complexes at temperatures within the measurement range. In the present work, the synthesis of a complex having a structure other than cubane, and still exhibiting dual emission is examined with the goal of preparing a film using this complex for device deployment. However, such complexes are not suitable for film formation by dry processes, such as evaporation, due to their non-volatility and non-sublimation properties. To overcome this drawback, film formation by sandwiching a complex in the polymeric network structure has been examined as an alternative method for dry processes. However, the luminescent properties might be changed by making the film depending on the complexes. ${ }^{27,28)}$ Therefore, it is desirable to develop a copper(I)-halide complex, in which the original luminescent properties of the powder are retained even in film state. Among the polymers used as binding agents, polymethyl methacrylate (PMMA) is preferred, because it is highly transparent, light-resistant, and easily forms a thin film. Copper(I)-halide complexes containing ligands coordinating through pnictogen and chalcogen atoms have been extensively investigated, but the complexes with ligands coordinating through other atoms are relatively underexplored. Herein, we focus on a novel polymeric copper(I)-bromide complex with an isocyanide ligand coordinating via carbon, and successfully verify the reversible luminescent mechanochromism in powder state. Furthermore, we succeeded in forming a 
thin film using PMMA as a binding agent, and demonstrated reversible luminescent mechanochromism even in film state.

\section{Experimental methods}

\subsection{General procedures}

All commercially available starting materials were used as-received, and solvents were used without any further purification. All the syntheses were conducted under argon atmosphere. Elemental analysis and Fourier-transform infrared (FT-IR) spectroscopy were performed using MT-6 CHN CORDER (Yanako) and MIR/NIR Frontier Fourier-transform infrared spectrometer (PerkinElmer), respectively. Grain size of the complex was measured using a laser-diffraction particle size analyzer SALD-3100 (Shimadzu). X-ray absorption spectroscopy (XAS) was performed at BL6N1, AichiSR. The incident x-ray energy was calibrated with the first main peak of potassium sulfate $\left(\mathrm{K}_{2} \mathrm{SO}_{4}\right)$ at $2481.7 \mathrm{eV}$. A powder sample from the synthesis below was mounted on carbon tape. The resulting XAS was processed using the Athena program to remove background intensities, normalize the intensities, and Fourier transform the $k^{3}$-weighted spectrum over a $k$ range of $2.5-10 \AA^{-1}$ with the Hanning window function. Crystal structures were determined using a Bruker V8 Venture single-crystal X-ray diffractometer at $-100{ }^{\circ} \mathrm{C}$ for single crystals, and a Rigaku RINT-2000 powder X-ray diffractometer (PXRD) for powder crystals. Thermogravimetry-differential thermal analysis (TG-DTA) was performed using Thermo plus EVO/TG-DTA 8120 (Rigaku) at a heating rate of $10 \mathrm{~K} / \mathrm{min}$. All the emission spectra were recorded on a JASCO FP-6200 spectrofluorometer with an Opto Sigma SCF-50S-37 long-pass filter under the irradiation of UV light $\left(\lambda_{\mathrm{ex}}=350 \mathrm{~nm}\right)$.

\subsection{Synthesis of $\left[\mathrm{Cu}_{4} \mathrm{Br}_{4}\left(\mathrm{PPh}_{3}\right)_{4}\right]$ and $\left[\mathrm{Cu}_{2} \mathrm{Br}_{2}(\mathrm{DIB})_{2}\left(\mathrm{PPh}_{2}\right)_{2}\right] \mathrm{n}$}

A mixture of $\mathrm{CuBr}(150 \mathrm{mg}, 1.05 \mathrm{mmol})$ and triphenylphosphine $\left(\mathrm{PPh}_{3} ; 274 \mathrm{mg}, 1.05\right.$ mmol) in toluene was refluxed for $3 \mathrm{~h}$, followed by cooling to obtain colorless crystals in $87 \%$ yield. Anal. calcd. for $\mathrm{C}_{18} \mathrm{H}_{15} \mathrm{CuBrP}$ : C, 53.28; H, 3.73. Found: C, 53.26; H, 3.64. Based on the single-crystal X-ray diffraction analysis, the obtained complex is $\left[\mathrm{Cu}_{4} \mathrm{Br}_{4}\left(\mathrm{PPh}_{3}\right)_{4}\right]$, having a cubane skeleton of $\left\{\mathrm{Cu}_{4} \mathrm{Br}_{4}\right\}$ with $\mathrm{Cu}-\mathrm{Cu}$ distances $\{3.0162(7)$, 3.0162(7), 3.4118(8), 3.4739(7), 3.4739(7), 3.4946(7) ^̊ \} (Fig. 1 and Table I). ${ }^{29)}$ Moreover, compared to the reported complexes $\left[\mathrm{Cu}_{4} \mathrm{Cl}_{4}\left(\mathrm{PPh}_{3}\right)_{4}\right]$ with $\mathrm{Cu}-\mathrm{Cu}$ distances $\{3.084(1)$, 3.084(1), 3.343(1), 3.404(1), 3.417(1), 3.417(1) ̊ $\}$ and $\left[\mathrm{Cu}_{4} \mathrm{I}_{4}\left(\mathrm{PPh}_{3}\right)_{4}\right]$ with $\mathrm{Cu}-\mathrm{Cu}$ distances $\{2.883(2), 2.894(2), 2.942(2), 3.002(2), 3.143(2), 3.204(2) \AA\},{ }^{22,30)}$ the $\left\{\mathrm{Cu}_{4} \mathrm{Br}_{4}\right\}$ core of $\left[\mathrm{Cu}_{4} \mathrm{Br}_{4}\left(\mathrm{PPh}_{3}\right)_{4}\right]$ was found to form a cubane skeleton like the $\left\{\mathrm{Cu}_{4} \mathrm{Cl}_{4}\right\}$ core of 
$\left[\mathrm{Cu}_{4} \mathrm{Cl}_{4}\left(\mathrm{PPh}_{3}\right)_{4}\right]$, but is different from the $\left\{\mathrm{Cu}_{4} \mathrm{I}_{4}\right\}$ core in $\left[\mathrm{Cu}_{4} \mathrm{I}_{4}\left(\mathrm{PPh}_{3}\right)_{4}\right]$, which forms a step skeleton. In general, the step skeleton is thermodynamically favorable over the cubane skeleton in the $\left[\mathrm{PR}_{3} \mathrm{CuX}\right]$ tetramer, in which the bulky functional group, such as triphenylphosphine and halogen with large atomic ion radius, are contained as ligands simultaneously. ${ }^{31)}$ From this examination, it was established that the margin of halogen ion size between the cubane and step skeletons is between bromide and iodide. In addition, $\left[\mathrm{Cu}_{4} \mathrm{Br}_{4}\left(\mathrm{PPh}_{3}\right)_{4}\right] \cdot \mathrm{CHCl}_{3}$ has been reported to form a step skeleton in crystal state. ${ }^{32)}$ This suggests that the crystal volume becomes larger than that with cubane skeleton by including solvent molecules in the crystal. This increased space enables the skeletal transformation to the thermodynamically stable step skeleton. However, the complex obtained herein was unable to form the step skeleton because of the insufficient space for solvent molecules to enter in the crystal lattice, resulting in the formation of the cubane skeleton.

Afterwards, a toluene solution of $\left[\mathrm{Cu}_{4} \mathrm{Br}_{4}\left(\mathrm{PPh}_{3}\right)_{4}\right](425 \mathrm{mg}, 1.05 \mathrm{mmol})$ was added to a solution of 1,4-diisocyanobenzene (DIB; $134 \mathrm{mg}, 1.05 \mathrm{mmol}$ ) in acetonitrile. The precipitate with a mean particle diameter of $1.62 \mu \mathrm{m}(\sigma=0.30 \mu \mathrm{m})$ was filtered after stirring for $12 \mathrm{~h}$ at $0{ }^{\circ} \mathrm{C}$ and washed with acetonitrile obtaining a white powder in $68 \%$ yield. Figure 2(a) shows the FT-IR spectra of the obtained complex with peaks at around $2137 \mathrm{~cm}^{-1}$ (assigned to $\mathrm{C} \equiv \mathrm{N}$ stretching vibration) and $2183 \mathrm{~cm}^{-1}$ (assigned to $\mathrm{Cu}-\mathrm{CN}$ stretching vibration). ${ }^{33,34)}$ Anal. calcd. for $\mathrm{C}_{20} \mathrm{H}_{14} \mathrm{~N}_{2} \mathrm{CuBrP}: \mathrm{C}, 52.59 ; \mathrm{H}, 3.09 ; \mathrm{N}, 6.13$. Found: C, 52.32; H, 3.31; N, 6.11. These analyses revealed that one phenyl group of $\mathrm{PPh}_{3}$ was removed to form $\left[\mathrm{Cu}_{2} \mathrm{Br}_{2}(\mathrm{DIB})_{2}\left(\mathrm{PPh}_{2}\right)_{2}\right]_{\mathrm{n}}$. To obtain more precise structural information, P K-edge XAS was performed at room temperature in fluorescence $\mathrm{x}$-ray yield mode. As shown in Fig. 3, three peaks were observed at $1.4,1.9$ and $2.3 \AA$ in the radial distance. The peak at $2.3 \AA$ corresponds to the $\mathrm{P}-\mathrm{Cu}$ bond on comparison with the literature, ${ }^{35)}$ and the peak at $1.4 \AA$ was expected to correspond to the P-C bond by inferring from the literature about the bond with oxygen, which has an atomic radius similar to carbon, namely the P-O bond. ${ }^{36)}$ Considering the results of FT-IR and elemental analysis, and the valence of phosphorus, the shoulder peak at $1.9 \AA$ could be a $\mathrm{P}-\mathrm{P}$ bond. Also, the local atomic environment of $\mathrm{P}$ was postulated to be $2+1+1$, i.e. two $\mathrm{C}$ atoms from two phenyl groups, one $\mathrm{P}$ atom, and one $\mathrm{Cu}$ atom from $\mathrm{Cu}-\mathrm{CN}$. The PXRD analysis results shown in Fig. 4 and Table I revealed that two $\mathrm{Cu}$ ions were cross-linked by two Br-ligands to form a planar rhombus $\left\{\mathrm{Cu}_{2} \mathrm{Br}_{2}\right\}$ core with equal $\mathrm{Cu}-\mathrm{Br}$ distances $\{2.486(9), 2.489(7) \AA\}$ and unequal bond angles $\left\{\mathrm{Cu}-\mathrm{Br}-\mathrm{Cu}, 107.7(3)^{\circ}, \mathrm{Br}-\mathrm{Cu}-\mathrm{Br}\right.$, 
$\left.72.3(3)^{\circ}\right\}$, similar to the $\left\{\mathrm{Cu}_{2} \mathrm{I}_{2}\right\}$ core with equal $\mathrm{Cu}-\mathrm{I}$ distances $\{2.80(2), 2.809(17) \AA\}$ and unequal bond angles $\left\{\mathrm{Cu}-\mathrm{I}-\mathrm{Cu}, \quad 82.8(7)^{\circ}, \quad \mathrm{I}-\mathrm{Cu}-\mathrm{I}, \quad 97.2(7)^{\circ}\right\} \quad$ in $\left[\mathrm{Cu}_{2} \mathrm{I}_{2}(\mathrm{DIB})_{2}\left(\mathrm{PPh}_{3}\right)_{2}\right] .{ }^{37-39)}$ The PXRD analysis also supports the notion that one phenyl group of $\mathrm{PPh}_{3}$ was removed. This elimination causes a $\mathrm{P}$ atom coordinated with a $\mathrm{Cu}$ ion in a $\left\{\mathrm{Cu}_{2} \mathrm{Br}_{2}\right\}$ core unit to bind to a $\mathrm{P}$ atom of another core unit, resulting in the formation of a P-P bridged copper(I) cluster complex having a $\left\{\mathrm{Cu}_{2} \mathrm{Br}_{2}\right\}$ cluster core. EXAFS also supports the presence of P-P bond. TG-DTA was performed to examine the thermal stability of the $\left[\mathrm{Cu}_{2} \mathrm{Br}_{2}(\mathrm{DIB})_{2}\left(\mathrm{PPh}_{2}\right)_{2}\right]_{\mathrm{n}}$ complex. As shown in Fig. 5, an endothermic peak was observed at around $135^{\circ} \mathrm{C}^{40)}$ and the TG curve displayed no mass change until $135{ }^{\circ} \mathrm{C}$, suggesting that the cleavage of the $\mathrm{Cu}-\mathrm{C}$ coordination bond occurred at around $135{ }^{\circ} \mathrm{C}$. Fig. 2(b) showed that the peak assigned to the $\mathrm{Cu}-\mathrm{CN}$ stretching vibration (2183 $\left.\mathrm{cm}^{-1}\right)$ shifted to smaller wavenumber $\left(2166 \mathrm{~cm}^{-1}\right)$ due to the formation of a $\mathrm{P}-\mathrm{CN}$ bond by heating to $135{ }^{\circ} \mathrm{C} .{ }^{40)}$ This result indicates that the thermal decomposition of $\left[\mathrm{Cu}_{2} \mathrm{Br}_{2}(\mathrm{DIB})_{2}\left(\mathrm{PPh}_{2}\right)_{2}\right]_{\mathrm{n}}$ produces diphenylcyanophosphine having $\mathrm{P}-\mathrm{CN}$ bonds. This is consistent with the decrease of TG curve above $180{ }^{\circ} \mathrm{C}$, and the endothermic broad peaks at $180-184{ }^{\circ} \mathrm{C}$ in Fig. 5, which correspond to the boiling points of diphenylcyanophosphine and isocyanobenzene (decomposition products), 180 and $183{ }^{\circ} \mathrm{C}$, respectively. ${ }^{41)}$

\section{Results and discussion}

\subsection{Luminescent properties in powder state}

$\left[\mathrm{Cu}_{4} \mathrm{Br}_{4}\left(\mathrm{PPh}_{3}\right)_{4}\right]$ exhibited blue emission $\left(\lambda_{\max }=452,477\right.$ and $\left.500 \mathrm{~nm}\right)$ under UV irradiation. In the excitation spectrum (monitor wavelength: $450 \mathrm{~nm}$ ), the peak at $359 \mathrm{~nm}$ was ascribed to the $\pi-\pi^{*}$ transition of $\mathrm{PPh}_{3} .{ }^{37)}$ Compared to the reported emission peak $\left(\lambda_{\max }=570 \mathrm{~nm}\right)$ of $\left[\mathrm{Cu}_{4} \mathrm{I}_{4}\left(\mathrm{PPh}_{3}\right)_{4}\right]$, the peak of $\left[\mathrm{Cu}_{4} \mathrm{Br}_{4}\left(\mathrm{PPh}_{3}\right)_{4}\right]$ shifted to a shorter wavelength. For the $\mathrm{Cu}_{4} \mathrm{X}_{4}$ clusters, where emission contributes to the ${ }^{3} \mathrm{CC}$ excited state, the $\mathrm{Cu}-\mathrm{Cu}$ distances determine the emission color, ${ }^{13,24,42)}$ where the energy level of ${ }^{3} \mathrm{CC}$ increases with increasing $\mathrm{Cu}-\mathrm{Cu}$ distance, resulting in shorter emission wavelength of $\left[\mathrm{Cu}_{4} \mathrm{Br}_{4}\left(\mathrm{PPh}_{3}\right)_{4}\right]$ than that of $\left[\mathrm{Cu}_{4} \mathrm{I}_{4}\left(\mathrm{PPh}_{3}\right)_{4}\right]$.

As shown in Fig. 6(a), $\left[\mathrm{Cu}_{2} \mathrm{Br}_{2}(\mathrm{DIB})_{2}\left(\mathrm{PPh}_{2}\right)_{2}\right]_{\mathrm{n}}$ exhibited bluish-green $\left(\lambda_{\max }=498 \mathrm{~nm}\right)$ and green $\left(\lambda_{\max }=515 \mathrm{~nm}\right)$ emissions under UV irradiation at 295 and $77 \mathrm{~K}$, respectively. This complex exhibited dual emission with $\lambda_{\max }=498$ and $515 \mathrm{~nm}$ only at $178 \mathrm{~K}$. Here, the temperature range showing dual emission was examined using a mixed system of liquid nitrogen and an organic solvent such as methanol, n-hexane and 
$\mathrm{n}$-heptane. No dual emission was observed in the emission spectra below $175 \mathrm{~K}$ and above $182 \mathrm{~K}$, suggesting that the temperature range for dual emission is within the temperature range of 175 to $182 \mathrm{~K}$, even when estimated over the widest temperature range. Such dual emission, caused by moving back and forth between the potential curves of ${ }^{3} \mathrm{X} / \mathrm{MLCT}$ and ${ }^{3} \mathrm{CC}$ through the thermal vibration pathway, is a characteristic phenomenon of a complex having a cubane cluster structure (Fig. 7). ${ }^{1,22,43)}$ Since the dual emission was observed in $\left[\mathrm{Cu}_{2} \mathrm{Br}_{2}(\mathrm{DIB})_{2}\left(\mathrm{PPh}_{2}\right)_{2}\right]_{\mathrm{n}}$, which does not have a cubane cluster structure, luminescent properties were examined using time-dependent density functional theory (TD-DFT) calculations, where the configuration of $\left[\mathrm{Cu}_{2} \mathrm{Br}_{2}(\mathrm{DIB})_{2}\left(\mathrm{PPh}_{2}\right)_{2}\right]_{\mathrm{n}}$ was treated as a hydrogen-terminated monomer $(\mathrm{n}=1$ in Fig. 4$)$. TD-DFT calculations were performed using the Gaussian09 software and the B3PW91 density functional 6-31G(d,p) was used as a basis set for $\mathrm{H}, \mathrm{C}, \mathrm{N}, \mathrm{P}, \mathrm{Cu}$, whereas lanl2dz was used for $\mathrm{Br}$. The calculations revealed that the emission of $\left[\mathrm{Cu}_{2} \mathrm{Br}_{2}(\mathrm{DIB})_{2}\left(\mathrm{PPh}_{2}\right)_{2}\right]_{\mathrm{n}}$ is derived from XLCT and (X+M)LCT, corresponding to HE and LE bands, respectively. This result suggests that the new excited state of $(\mathrm{X}+\mathrm{M}) \mathrm{LCT}$ was generated via the formation of the P-P bridged copper(I) cluster structure. In other words, the CC transition may appear in the cubane skeleton, while the $(\mathrm{X}+\mathrm{M}) \mathrm{LCT}$ transition may appear in the P-P-bridged cluster structure, which promoted the appearance of a new excited state of $(\mathrm{X}+\mathrm{M}) \mathrm{LCT}$ transition compared to $\left[\mathrm{Cu}_{2} \mathrm{I}_{2}(\mathrm{DIB})_{2}\left(\mathrm{PPh}_{3}\right)_{2}\right] .{ }^{44,45)}$ According to the mechanism of thermochromism, in which the emission of $\left[\mathrm{Cu}_{2} \mathrm{Br}_{2}(\mathrm{DIB})_{2}\left(\mathrm{PPh}_{2}\right)_{2}\right]_{\mathrm{n}}$ changes with temperature, the potential curves of XLCT and $(\mathrm{X}+\mathrm{M}) \mathrm{LCT}$ are in contact via a low-potential barrier, and the external temperature enables moving back and forth between the two potential curves. Therefore, $178 \mathrm{~K}$ was identified as a unique temperature at which the complex $\left[\mathrm{Cu}_{2} \mathrm{Br}_{2}(\mathrm{DIB})_{2}\left(\mathrm{PPh}_{2}\right)_{2}\right]_{\mathrm{n}}$ displays dual emission.

\subsection{Luminescent mechanochromism in powder state}

The color of solid $\left[\mathrm{Cu}_{2} \mathrm{Br}_{2}(\mathrm{DIB})_{2}\left(\mathrm{PPh}_{2}\right)_{2}\right]_{\mathrm{n}}$ shifted from white to yellow when grinding in a mortar with a pestle. The mean particle diameter after grinding was $1.15 \mu \mathrm{m}(\sigma=0.25$ $\mu \mathrm{m})$. The luminescent color changed from bluish-green to yellow $\left(\lambda_{\max }=529 \mathrm{~nm}\right)$. After grinding, the complex was dipped in acetonitrile and dried, whereby both appearance color and luminescent color returned to the initial ones (Fig. 8(a)). Since the TG-DTA result suggests that thermal decomposition occurs at $\sim 135^{\circ} \mathrm{C}$, the luminescent color change due to annealing was examined at temperatures below $135{ }^{\circ} \mathrm{C}$. As shown in Fig. 8(b), the luminescent color returned to the initial one upon annealing at $100{ }^{\circ} \mathrm{C}$ for $5 \mathrm{~h}$, as well as 
upon dipping in acetonitrile for $2 \mathrm{~h}$. The shift in emission wavelength due to luminescent mechanochromism has been generally attributed to several structural factors, such as $\mathrm{Cu}-$ $\mathrm{Cu}$ interactions in $\mathrm{Cu}(\mathrm{I})$ systems, as well as crystal packing, molecular arrangements, and inter/intramolecular interactions. ${ }^{5,11)}$ To investigate the reversible behavior of the emission peak, the structural change was examined by the PXRD analyses of the complex before and after grinding (Fig. 9(a)). The diffraction peaks after grinding either decrease or disappear compared to those before grinding. A plausible explanation to this phenomenon is the change of the crystalline phase to amorphous by grinding. It is possible that the emission peak of $\left[\mathrm{Cu}_{2} \mathrm{Br}_{2}(\mathrm{DIB})_{2}\left(\mathrm{PPh}_{2}\right)_{2}\right]_{\mathrm{n}}$ shifts to longer wavelength because of the disorder of the crystal lattice due to grinding and the accompanying change in intermolecular interactions. Dipping in acetonitrile and subsequent evaporation resulted in the reappearance of the initial intense and sharp reflection peaks, suggesting that crystalline phase state was restored due to lattice repacking, where the intermolecular arrangement was modified. Therefore, PXRD results show that the mechanism of this mechanochromism originates from the change between the crystalline and the amorphous state.

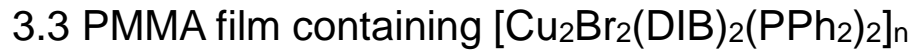

The formation and luminescent properties of a thin film containing $\left[\mathrm{Cu}_{2} \mathrm{Br}_{2}(\mathrm{DIB})_{2}\left(\mathrm{PPh}_{2}\right)_{2}\right]_{\mathrm{n}}$ were examined. Vacuum evaporation is used in general for film formation in the fabrication of OLED devices; however, this method is not feasible in this case, due to the non-volatile and non-sublimable properties of $\left[\mathrm{Cu}_{2} \mathrm{Br}_{2}(\mathrm{DIB})_{2}\left(\mathrm{PPh}_{2}\right)_{2}\right]_{\mathrm{n}}$, as shown in Fig. 5. Therefore, a cast method using PMMA as a binding agent was adopted. The $\left[\mathrm{Cu}_{2} \mathrm{Br}_{2}(\mathrm{DIB})_{2}\left(\mathrm{PPh}_{2}\right)_{2}\right]_{\mathrm{n}}(20.0 \mathrm{mg})$ suspension added to a chloroform solution of PMMA (0.5 wt $\%)$ was dropped on a slide glass, and dried to obtain a thin film containing $\left[\mathrm{Cu}_{2} \mathrm{Br}_{2}(\mathrm{DIB})_{2}\left(\mathrm{PPh}_{2}\right)_{2}\right]_{\mathrm{n}}$ of thickness $50 \mu \mathrm{m} \pm 2 \mu \mathrm{m}$. The emission spectra of $\left[\mathrm{Cu}_{2} \mathrm{Br}_{2}(\mathrm{DIB})_{2}\left(\mathrm{PPh}_{2}\right)_{2}\right]_{\mathrm{n}}$ were recorded in film state at 295, 178, and $77 \mathrm{~K}$. As shown in Fig. 6(b), $\left[\mathrm{Cu}_{2} \mathrm{Br}_{2}(\mathrm{DIB})_{2}\left(\mathrm{PPh}_{2}\right)_{2}\right]_{\mathrm{n}}$ in film state exhibited the same bluish-green $\left(\lambda_{\max }=498 \mathrm{~nm}\right)$ and green $\left(\lambda_{\max }=515 \mathrm{~nm}\right)$ emissions as the powder state at 295 and $77 \mathrm{~K}$, respectively, and showed dual emission $\left(\lambda_{\max }=498\right.$ and $\left.515 \mathrm{~nm}\right)$ at $178 \mathrm{~K}$. Based on this result, it was established that the luminescent properties of the film state remained the same as those of the powder state. As a demonstration of the luminescent mechanochromism of $\left[\mathrm{Cu}_{2} \mathrm{Br}_{2}(\mathrm{DIB})_{2}\left(\mathrm{PPh}_{2}\right)_{2}\right]_{\mathrm{n}}$ in film state, the surface of the film was examined under UV irradiation before and after rubbing with a spatula. The rubbed part exhibited yellow 
emission, and the other parts remained bluish-green, which is the same as the luminescent color before rubbing (Fig. 10(a) and (b)). When this cast film was immersed in a mixture of acetonitrile and chloroform $(\mathrm{v}: \mathrm{v}=1: 1)$ for $12 \mathrm{~h}$ and dried, the yellow emission of the rubbed parts returned to the initial bluish-green emission (Fig. 10(c)). Furthermore, this recovery of the luminescent color due to annealing at $100{ }^{\circ} \mathrm{C}$ for $20 \mathrm{~h}$ was confirmed, as shown in Fig. 10(d). The correlation between the reciprocal $\lambda_{\max }$ and the annealing time after grinding was examined for the powder and film states. As shown in Fig. 11, the reciprocal $\lambda_{\max }$ was proportional to annealing time for both states. The annealing times required to return to the initial $\lambda_{\max }$ were 4 and $20 \mathrm{~h}$ in the powder and film states, respectively, and $\lambda_{\max }$ remained constant in both cases on further heating, meaning that the annealing time required to return to the initial $\lambda_{\max }$ was about 5 times longer in film state than that in powder state because of the thermal absorption of PMMA by itself. Further polymer material studies are required for reducing the annealing time. Figure 8(c) and (d) show the emission spectra of the film state in the cases of solvent immersion and annealing after grinding. The profile of the emission spectra was perfectly identical, meaning that both treatments have the same effect on the recovery of the luminescent color after grinding in film state. The mechanism of the reversible luminescent mechanochromism in film state was investigated by PXRD. As shown in Fig. 9(b), the diffraction peaks after grinding disappear or decrease compared to those before grinding, as well as in powder state. After solvent immersion and annealing, the diffraction peaks reverted to those before grinding. This observation led to the conclusion that the mechanism of the reversible luminescent mechanochromism in film state is the same as in powder state, and it originates from the change between the crystalline phase and the amorphous phase.

\section{Summary}

A polymeric copper(I) complex $\left[\mathrm{Cu}_{2} \mathrm{Br}_{2}(\mathrm{DIB})_{2}\left(\mathrm{PPh}_{2}\right)_{2}\right]_{\mathrm{n}}$ was synthesized, which exhibited bluish-green emission under UV irradiation via the formation of $\left[\mathrm{Cu}_{4} \mathrm{Br}_{4}\left(\mathrm{PPh}_{3}\right)_{4}\right]$ with a cubane skeleton. The PXRD analysis confirmed that $\left[\mathrm{Cu}_{2} \mathrm{Br}_{2}(\mathrm{DIB})_{2}\left(\mathrm{PPh}_{2}\right)_{2}\right]_{\mathrm{n}}$ in powder state forms a P-P bridged copper(I) cluster complex with a planar rhombic $\left\{\mathrm{Cu}_{2} \mathrm{Br}_{2}\right\}$ cluster core. TD-DFT calculations revealed that the emission of $\left[\mathrm{Cu}_{2} \mathrm{Br}_{2}(\mathrm{DIB})_{2}\left(\mathrm{PPh}_{2}\right)_{2}\right]_{\mathrm{n}}$ originates from XLCT and $(\mathrm{X}+\mathrm{M}) \mathrm{LCT}$ (HE and LE bands, respectively). The latter transition was expected to appear upon formation of the P-P bridged cluster structure. At low temperature $(77 \mathrm{~K})$, only emission from LE is observed. With increasing temperature, internal conversion due to thermal vibration from LE to HE occurs, where double emission 
peaks appear, and only the emission from HE band is observed at room temperature. $\left[\mathrm{Cu}_{2} \mathrm{Br}_{2}(\mathrm{DIB})_{2}\left(\mathrm{PPh}_{2}\right)_{2}\right]_{\mathrm{n}}$ showed reversible luminescent mechanochromism due to solvent immersion and annealing, which is related to the conversion between crystal and amorphous phase. A thin film containing $\left[\mathrm{Cu}_{2} \mathrm{Br}_{2}(\mathrm{DIB})_{2}\left(\mathrm{PPh}_{2}\right)_{2}\right]_{\mathrm{n}}$ was prepared successfully by a casting method, using PMMA as a binding agent. The reversible luminescent mechanochromism by dipping and annealing was confirmed even in film state. The complex described herein has significant potential application in displays, optical recording media, and pressure sensors.

\section{Acknowledgments}

The authors thank Mr. Takuya Hayakawa of EUREKA Corp. for measuring emission spectra and for analyzing PXRD. We are also grateful to Dr. Koichi Ozaki of Toray Research Center Inc. for analyzing P K-edge EXAFS. The EXAFS experiments were conducted at the BL6N1 of Aichi Synchrotron Radiation Center, Aichi Science \& Technology Foundation, Aichi, Japan (Proposal No. 201904073). We also thank the Saitama Industrial Technology Center for measuring particle size distribution by the laser diffraction method. We would like to thank Editage (www.editage.com) for English language editing. 


\section{References}

1) E. Cariati, E. Lucenti, C. Botta, U. Giovanella, D. Marinotto, and S. Righetto, Coord. Chem. Rev. 306, 566 (2016).

2) A. Liske, L. Wallbaum, T. Hölzel, J. Föller, M. Gernert, B. Hupp, C. Ganter, C. M. Marian, and A. Steffen, Inorg. Chem. 58, 5433 (2019).

3) A. Neshat, R. B. Aghakhanpour, P. Mastrorilli, S. Todisco, F. Molani, and A. Wojtczak, Polyhedron. 154, 217 (2018).

4) A. Aguirrechu-Comerón, R. Hernández-Molina, P. Rodríguez-Hernández, A. Muñoz, U. R. Rodríguez-Mendoza, V. Lavín, R. J. Angel, and J. Gonzalez-Platas, Adv. Mater. Inorg. Chem. 55, 7476 (2016).

5) T. Lu, J.-Y. Wang, D. Tu, Z.-N. Chen, X.-T. Chen, and Z.-L. Xue, Inorg. Chem. 57, 13618 (2018).

6) K. Chen, M. M. Nenzel, T. M. Brown, and V. J. Catalano, Inorg. Chem. 54, 6900 (2015).

7) Q. Xiao, J. Zheng, M. Li, S.-Z. Zhan, J.-H. Wang, and D. Li, Inorg. Chem. 53, 11604 (2014).

8) Q. Benito, I. Maurin, T. Cheisson, G. Nocton, A. Fargues, A. Garcia, C. Martineau, T. Gacoin, J.-P. Boilot, and S. Perruchas, Chem. Eur. J. 21, 5892 (2015).

9) X. Zhang, Z. Chi, Y. Zhang, S. Liu, and J. Xu, J. Mater. Chem. C 1, 3376 (2013).

10) D. Parasar, R. M. Almotawa, N. B. Jayaratna, Y. S. Ceylan, T. R. Cundari, M. A. Omary, and H. V. Rasika Dias, Organometallics 37, 4105 (2018).

11) N. Kathewad, S. Pal, R. L. Kumawat, Md. E. Ali, and S. Khan, Eur. J. Inorg. Chem. 2018, 2518 (2018).

12) C. M. Brown, V. Carta, and M. O. Wolf, Chem. Mater. 30, 5786 (2018).

13) X.-C. Shan, F.-L. Jiang, H.-b. Zhang, X.-Y. Qian, L. Chen, M.-Y. Wu, S. A. AL-Thabaiti, and M.-C. Hong, Chem. Commun. 49, 10227 (2013).

14) J. Troyano, J. Perles, P. Amo-Ochoa, J. I. Mart\&nez, M. C. Gimeno, V. Fernández-Moreira, F. Zamora, and S. Delgado, Chem. Eur. J. 22, 18027 (2016).

15) S. Perruchas, X. F. Le Goff, S. Maron, I. Maurin, F. Guillen, A. Garcia, T. Gacoin, and J.-P. Boilot, J. Am. Chem. Soc. 132, 10967 (2010).

16) B. Huitorel, Q. Benito, A. Fargues, A. Garcia, T. Gacoin, J.-P. Boilot, S. Perruchas, and F. Camerel, Chem. Mater. 28, 8190 (2016).

17) A. Kobayashi, Y. Yoshida, M. Yoshida, and M. Kato, Chem. Eur. J. 24, 14750 (2018).

18) X.-C. Shan, F.-L. Jiang, L. Chen, M.-Y. Wu, J. Pan, X.-Y. Wan, and M.-C. Hong, J. 
Mater. Chem. C 1, 4339 (2013).

19) B. Hupp, J. Nitsch, T. Schmitt, R. Bertermann, K. Edkins, F. Hirsch, I. Fischer, M. Auth, A. Sperlich, and A. Steffen, Angew. Chem. Int. Ed. 57, 13671 (2018).

20) K. R. Kyle, C. K. Ryu, J. A. DiBenedetto, and P. C. Ford, J. Am. Chem. Soc. 113, 2954 (1991).

21) B. Huitorel, H. E. Moll, M. Cordier, A. Fargues, A. Garcia, F. Massuyeau, C. Martineau-Corcos, T. Gacoin, and S. Perruchas, Inorg. Chem. 56, 12379 (2017).

22) H. Kitagawa, Y. Ozawa, and K. Toriumi, Chem. Commun. 46, 6302 (2010).

23) S. Nagaoka, Y. Ozawa, K. Toriumi, and M. Abe, Chem. Lett. 47, 1101 (2018).

24) P. C. Ford, E. Cariati, and J. Bourassa, Chem. Rev. 99, 3625 (1999).

25) F. D. Angelis, S. Fantacci, A. Sgamellotti, E. Cariati, R. Ugo, and P. C. Ford, Inorg. Chem. 45, 10576 (2006).

26) Q. Benito, X. F. Le Goff, G. Nocton, A. Fargues, A. Garcia, A. Berhault, S. Kahlal, J.-Y. Saillard, C. Martineau, J. Trébosc, T. Gacoin, J.-P. Boilot, and S. Perruchas, Inorg. Chem. 54, 4483 (2015).

27) M. Bachmann, D. Suter, O. Blacque, and K. Venkatesan, Inorg. Chem. 55, 4733 (2016).

28) S. B. Meshkova, P. G. Doga, A. V. Kiriyak, and A. A. Kucher, Russ. J. Inorg. Chem. 61, 78 (2016).

29) Crystal data for $\left[\mathrm{Cu}_{4} \mathrm{Br}_{4}\left(\mathrm{PPh}_{3}\right)_{4}\right] \mathrm{CCDC}-1880551$.

30) F. Han, J. Li, H. Zhang, T Wang, Z. Lin, and H. Xia, Chem. Eur. J. 21, 565 (2015).

31) M. R. Churchill, B. G. DeBoer, and D. J. Donovan, Inorg. Chem. 14, 617 (1975).

32) M. R. Churchill, and K. L. Kalra, Inorg. Chem. 13, 1427 (1974).

33) J. Díez, M. P. Gamasa, J. Gimeno, M. Lanfranchi, and A. Tiripicchio, J. Organomet. Chem. 3, 677 (2001).

34) G. A. Bowmaker, B. J. Kennedy, and J. C. Reid, Inorg. Chem. 37, 3968 (1998).

35) V. Gandin, F. Tisato, A. Dolmella, M. Pellei, C. Santini, M. Giorgetti, C. Marzano, and M. Porchia, J. Med. Chem., 57, 4745 (2014).

36) I. Persson, M. Trublet, and W. Klysubun, J. Phys. Chem. A, 122, 7413, (2018).

37) T. Hayakawa, C. Nanzan, M. Hashimoto, H. Teramae, and T. Sakata, Jpn. J. Appl. Phys. 57, 081601 (2018).

38) Crystal data for $\left[\mathrm{Cu}_{2} \mathrm{I}_{2}(\mathrm{DIB})_{2}\left(\mathrm{PPh}_{3}\right)_{2}\right] \mathrm{CCDC}-1567192$.

39) Crystal data for $\left[\mathrm{Cu}_{2} \mathrm{Br}_{2}(\mathrm{DIB})_{2}\left(\mathrm{PPh}_{2}\right)_{2}\right]_{\mathrm{n}} \mathrm{CCDC}-1889062$.

40) C. E. Jones, and K. J. Coskran, Inorg. Chem. 10, 1664 (1971). 
41) J. Brierley, J. I. Dickstein, and S. Trippett, Phosphorus, Sulfur Silicon Relat. Elem., 7, 167 (1979).

42) Q. Benito, X. F. Le Goff, S. Maron, A. Fargues, A. Garcia, C. Martineau, F. Taulelle, S. Kahlal, T. Gacoin J.-P. Boilot, and S. Perruchas, J. Am. Chem. Soc. 136, 11311 (2014).

43) S. Perruchas, C. Tard, X. F. Le Goff, A. Fargues, A. Garcia, S. Kahlal, J.-Y. Saillard, T. Gacoin, and J.-P. Boilot, Inorg. Chem. 50, 10682 (2011).

44) R. N. Nurmukhametov, A. V. Shapovalov, and D. Y. Antonov, EPJ Web of Conferences, 132, 03052 (2017).

45) Y. V. Nelyubina, L. N. Puntus, and K, A. Lyssenko, Chem. Eur. J., 20, 2860 (2014). 


\section{Figure captions}

Fig. 1. (Color online) Partial view of $\left[\mathrm{Cu}_{4} \mathrm{Br}_{4}\left(\mathrm{PPh}_{3}\right)_{4}\right]$ packing structure.

Fig. 2. (Color online) FT-IR spectra of $\left[\mathrm{Cu}_{2} \mathrm{Br}_{2}(\mathrm{DIB})_{2}\left(\mathrm{PPh}_{2}\right)_{2}\right]_{\mathrm{n}}$ (a) before and (b) after annealing at $130{ }^{\circ} \mathrm{C}$ for $5 \mathrm{~min}$.

Fig. 3. (Color online) Fourier-transform of $\mathrm{P}$ K-edge EXAFS spectrum of $\left[\mathrm{Cu}_{2} \mathrm{Br}_{2}(\mathrm{DIB})_{2}\left(\mathrm{PPh}_{2}\right)_{2}\right]_{\mathrm{n}}$.

Fig. 4. (Color online) (a) Chemical structure and (b) partial view of molecular structure of $\left[\mathrm{Cu}_{2} \mathrm{Br}_{2}(\mathrm{DIB})_{2}\left(\mathrm{PPh}_{2}\right)_{2}\right]_{\mathrm{n}}$.

Fig. 5. (Color online) TG-DTA profiles of $\left[\mathrm{Cu}_{2} \mathrm{Br}_{2}(\mathrm{DIB})_{2}\left(\mathrm{PPh}_{2}\right)_{2}\right]_{\mathrm{n}}$.

Fig. 6. (Color online) Emission spectra of $\left[\mathrm{Cu}_{2} \mathrm{Br}_{2}(\mathrm{DIB})_{2}\left(\mathrm{PPh}_{2}\right)_{2}\right]_{\mathrm{n}}$ at 77,178 , and $295 \mathrm{~K}$ in (a) powder and (b) film states.

Fig. 7. (Color online) Potential diagram and electron transfer at each temperature in the dual-emission system.

Fig. 8. (Color online) Reversible luminescent mechanochromism properties in powder state. (a) Dipping in acetonitrile for $2 \mathrm{~h}$, and (b) annealing at $100{ }^{\circ} \mathrm{C}$ for $5 \mathrm{~h}$. Reversible luminescent mechanochromism properties in film state. (c) Dipping in the mixture of acetonitrile and chloroform for $12 \mathrm{~h}$, and (d) annealing at $100{ }^{\circ} \mathrm{C}$ for $20 \mathrm{~h}$.

Fig. 9. (Color online) PXRD patterns of $\left[\mathrm{Cu}_{2} \mathrm{Br}_{2}(\mathrm{DIB})_{2}\left(\mathrm{PPh}_{2}\right)_{2}\right]_{\mathrm{n}}$ in (a) powder and (b) film states.

Fig. 10. (Color online) Luminescent view (a) before (b) after rubbing, (c) further dipping in a $1: 1(\mathrm{v}: \mathrm{v})$ mixture of acetonitrile and chloroform for $12 \mathrm{~h}$ or (d) further annealing at $100{ }^{\circ} \mathrm{C}$ for $20 \mathrm{~h}$.

Fig. 11. (Color online) Correlation between $\ln \left(1 / \lambda_{\max }\right)$ and annealing time in powder and film states. 
Table I. Crystal parameters of $\left[\mathrm{Cu}_{4} \mathrm{Br}_{4}\left(\mathrm{PPh}_{3}\right)_{4}\right]$ and $\left[\mathrm{Cu}_{2} \mathrm{Br}_{2}(\mathrm{DIB})_{2}\left(\mathrm{PPh}_{2}\right)_{2}\right]_{\mathrm{n}}$.

\begin{tabular}{|c|c|c|}
\hline & {$\left[\mathrm{Cu}_{4} \mathrm{Br}_{4}\left(\mathrm{PPh}_{3}\right)_{4}\right]$} & {$\left[\mathrm{Cu}_{2} \mathrm{Br}_{2}(\mathrm{DIB})_{2}\left(\mathrm{PPh}_{2}\right)_{2}\right]_{\mathrm{n}}$} \\
\hline $\begin{array}{c}\text { Crystal system, } \\
\text { space group }\end{array}$ & Orthorhombic, & Monoclinic, \\
$\mathrm{Pbcn}$ & $\mathrm{P}{ }_{1} / \mathrm{c}$ \\
\hline$a, b, c, \AA$ & $17.5115(4), 20.5013(5)$, & $14.145(9), 8.922(6)$, \\
& $18.0935(4)$ & $13.211(8)$ \\
\hline$\alpha, \beta, \gamma, \mathrm{deg}$ & $90,90,90$ & $104.29(5), 90,90$ \\
\hline$V, \AA^{3}$ & $6495.7(3)$ & $1613.7(18)$ \\
\hline Density, g/cm $\mathrm{cm}^{3}$ & 1.659 & 1.880 \\
\hline$Z$ & 4 & 0.1151 \\
\hline$R_{w p}$ & 0.0367 & 4.1944 \\
\hline$S$ & 1.148 & \\
\hline
\end{tabular}


Figures

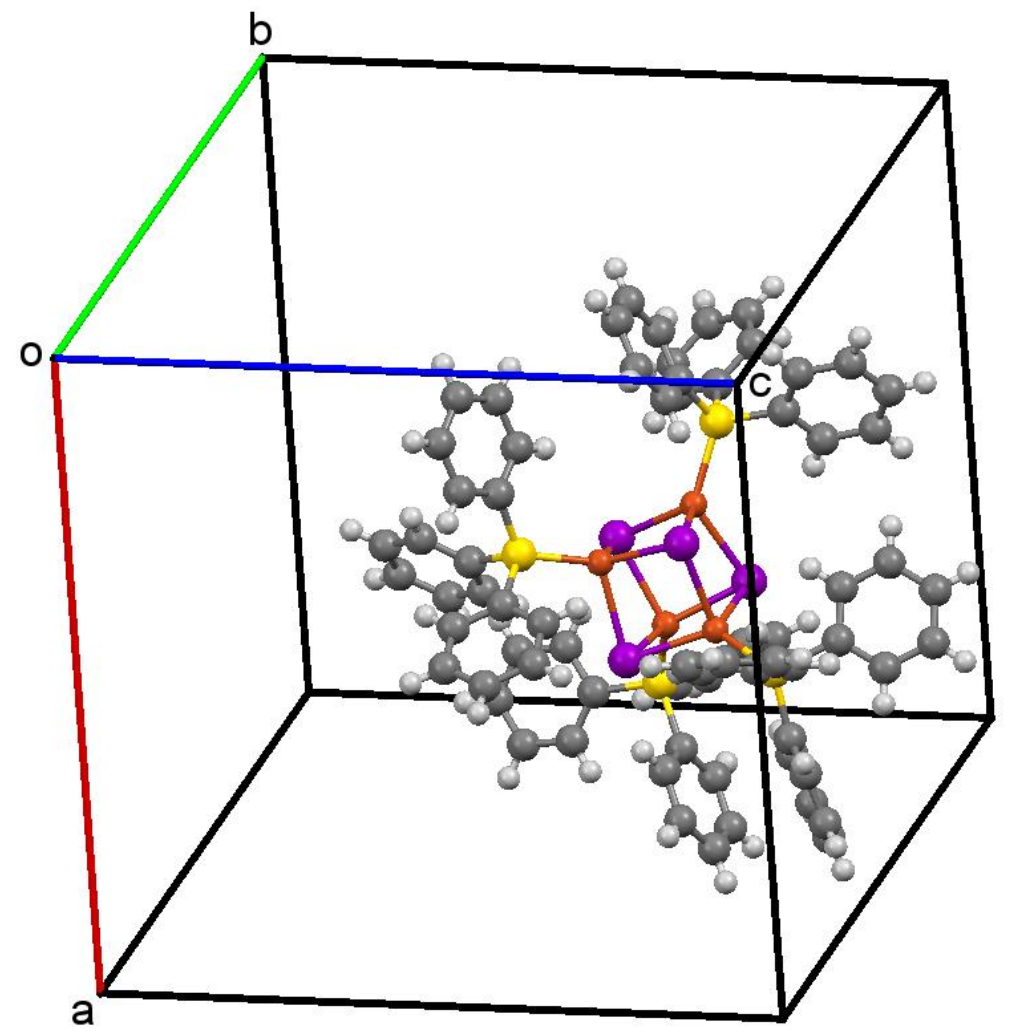

Fig. 1

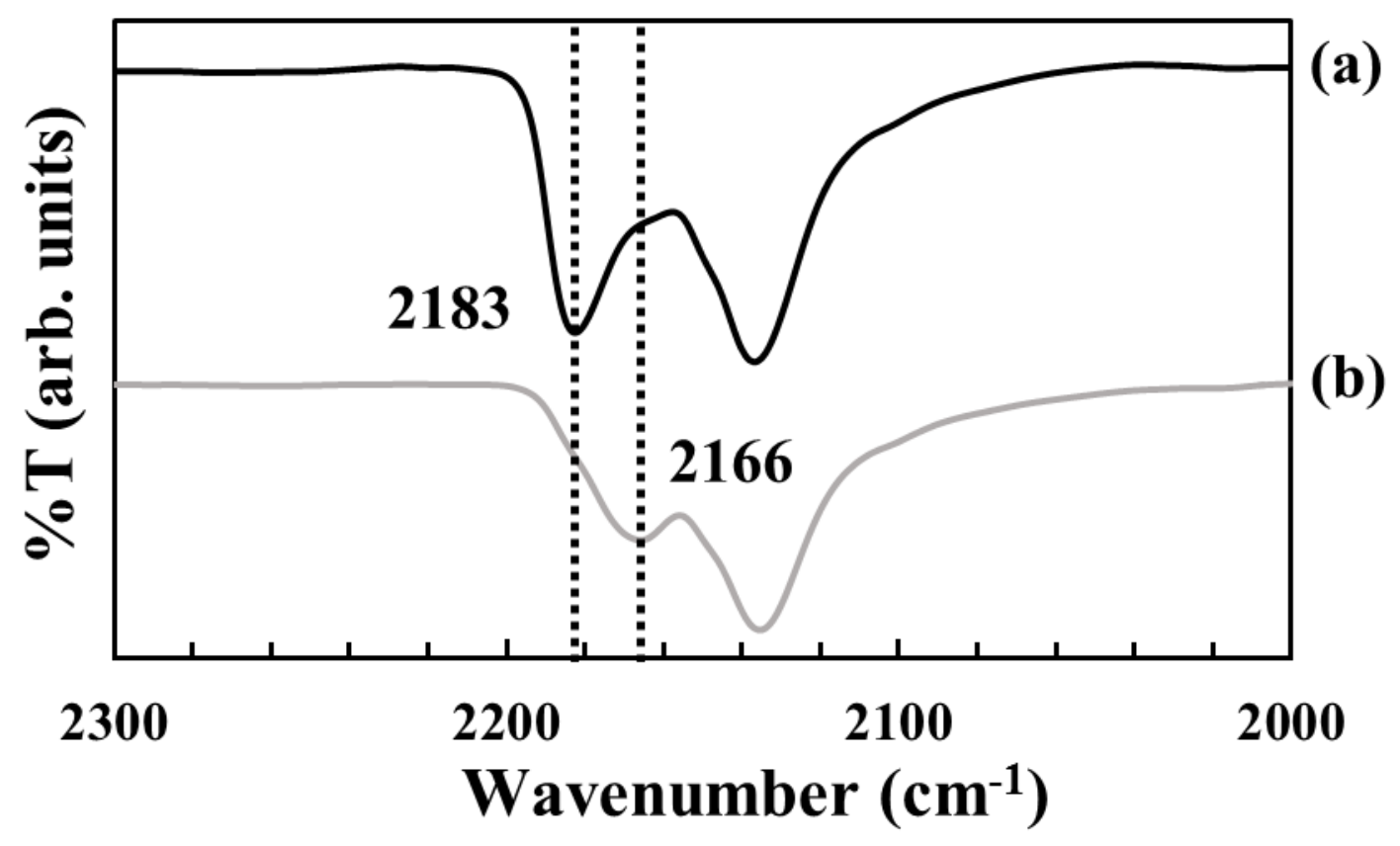

Fig. 2 


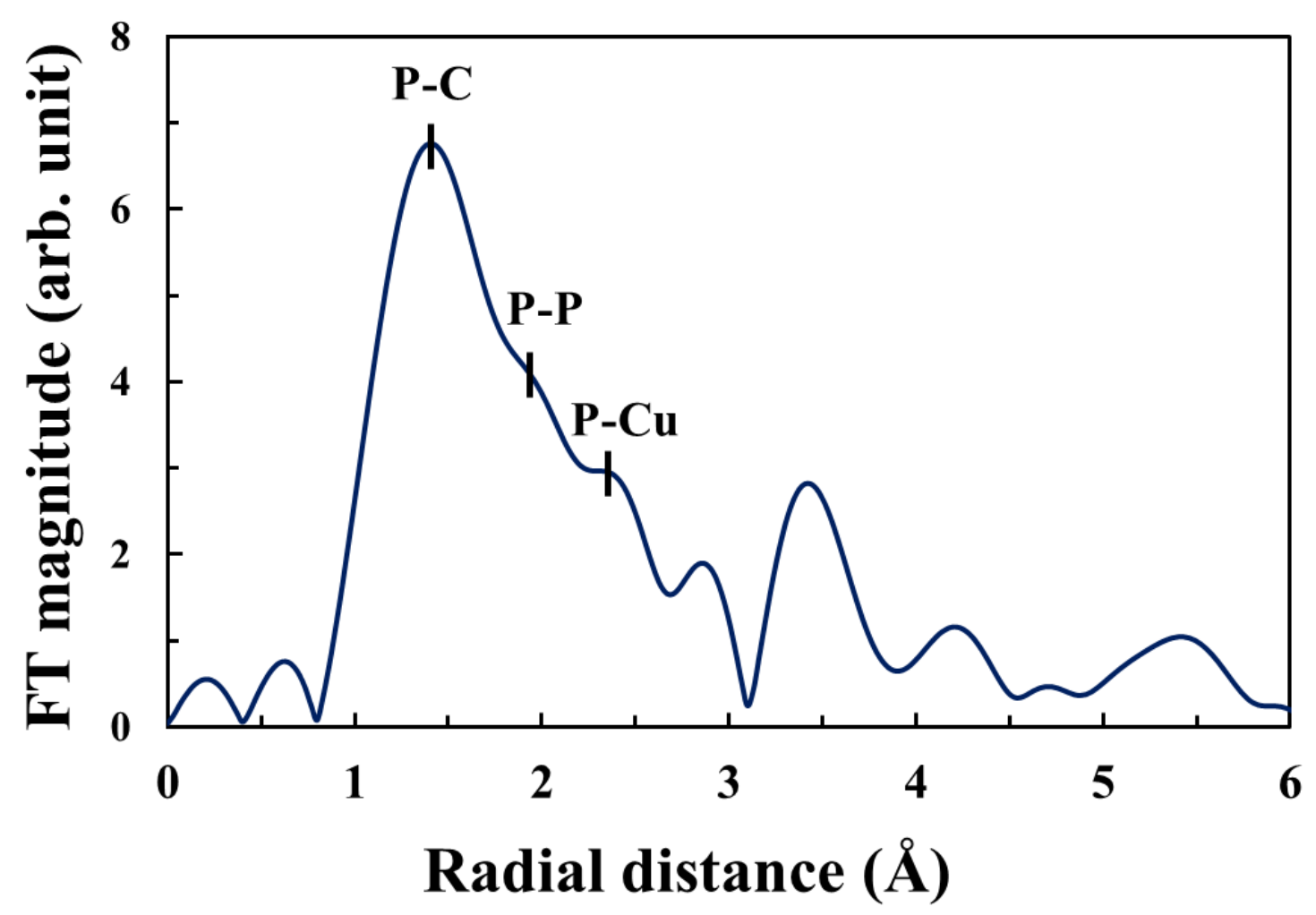

Fig. 3 
(a)

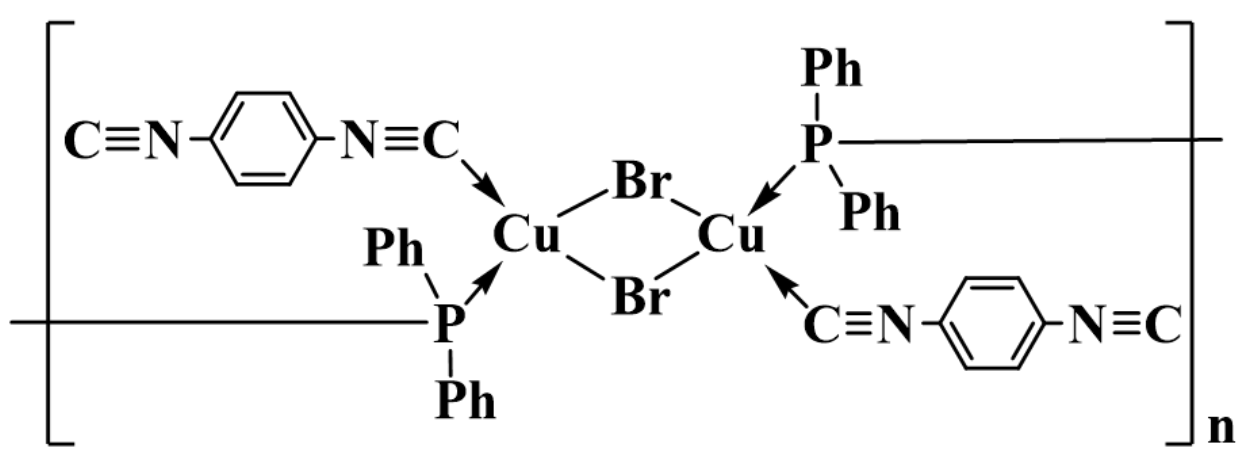

(b)

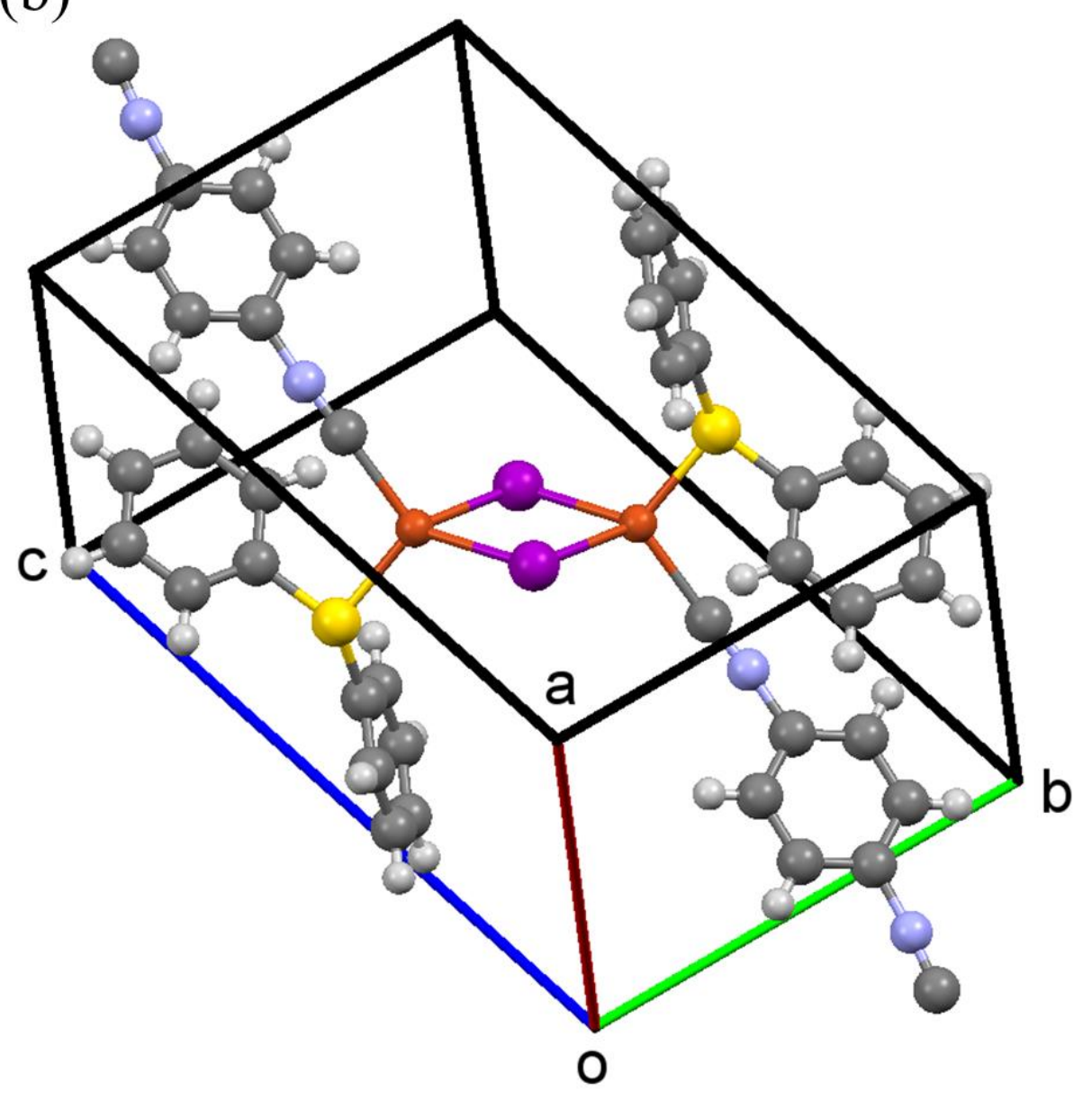

Fig. 4 


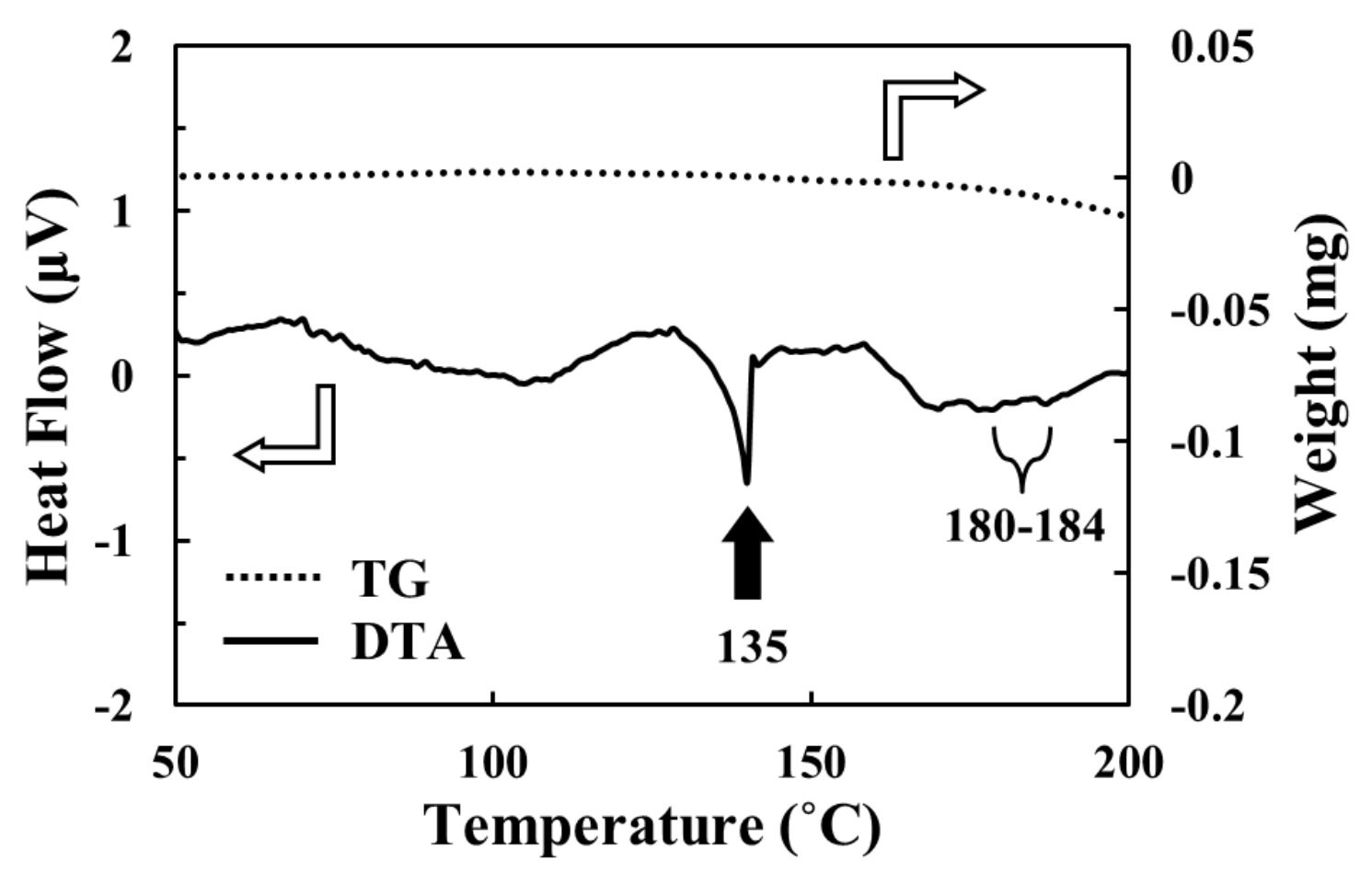

Fig. 5

(a)

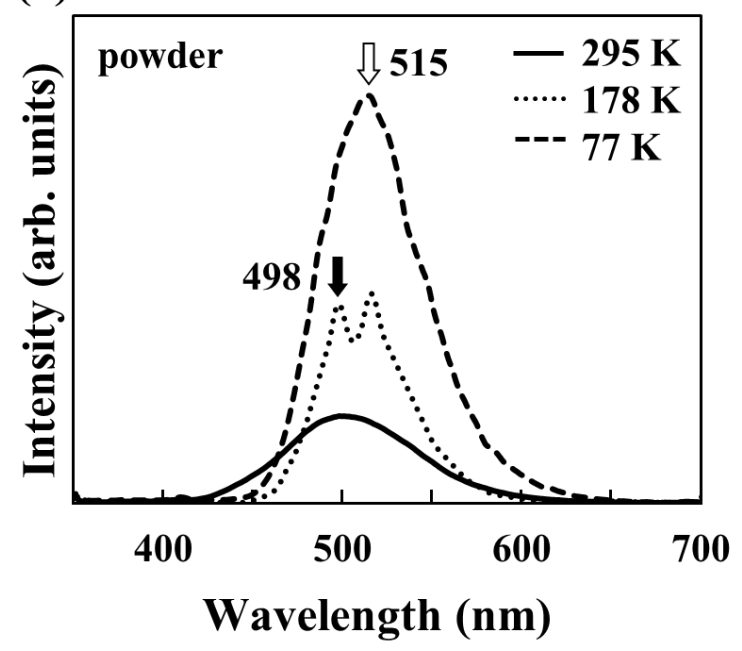

(b)

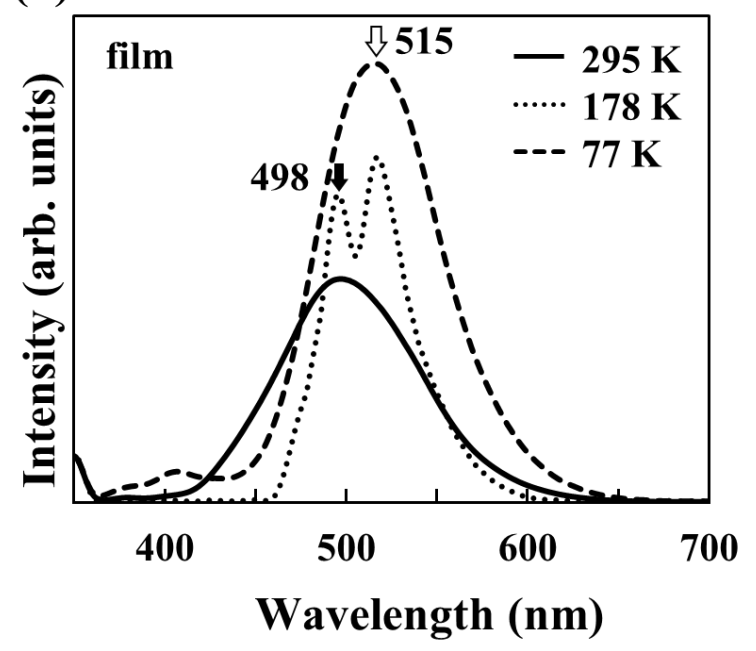

Fig. 6 


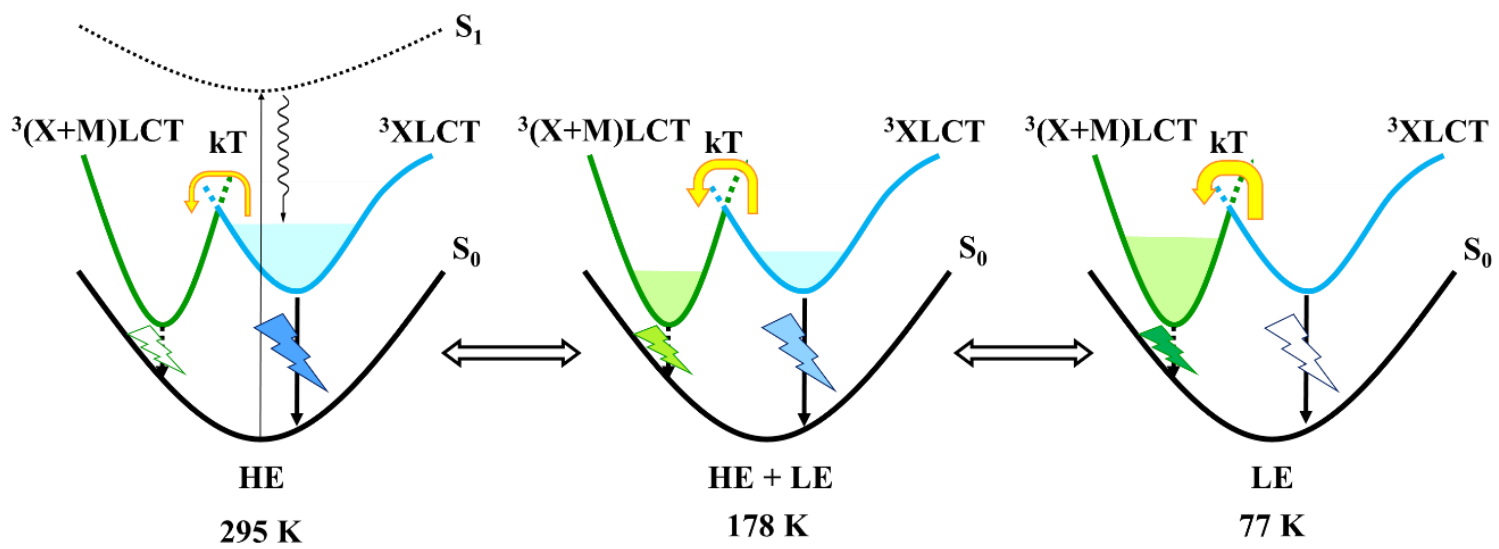

Fig. 7

(a)

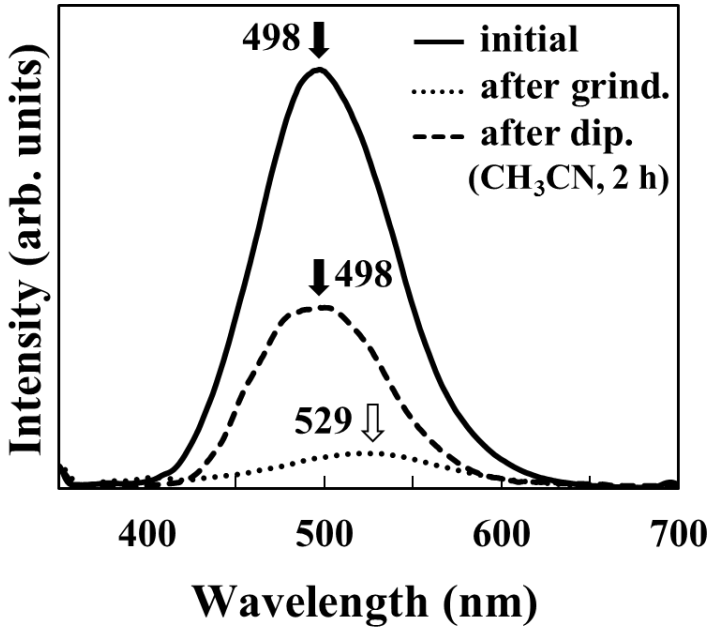

(c)

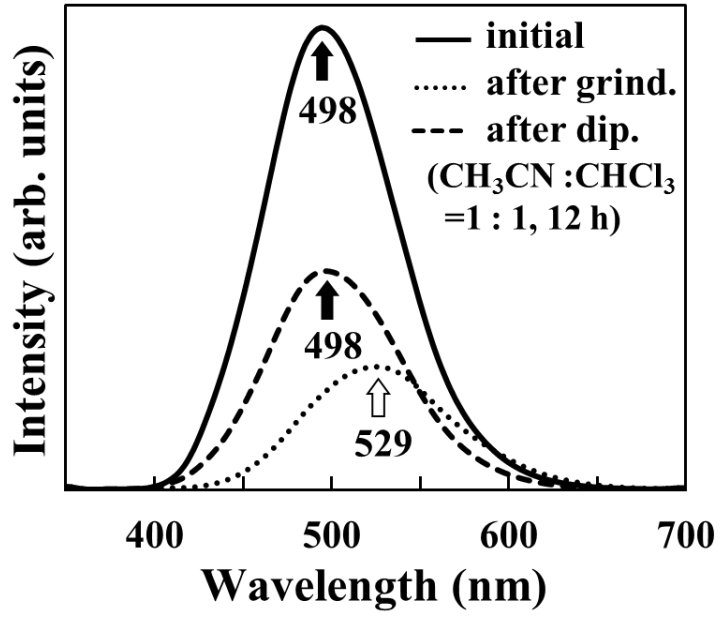

(b)

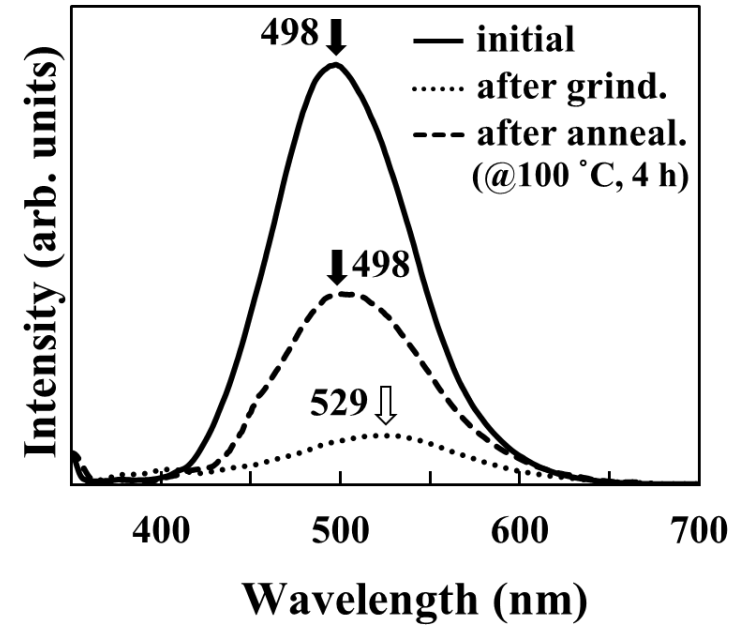

(d)

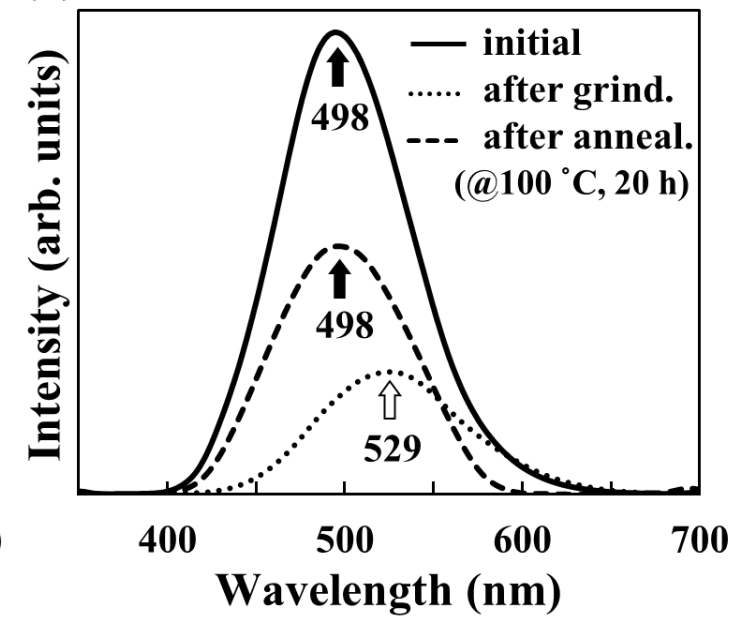

Fig. 8 

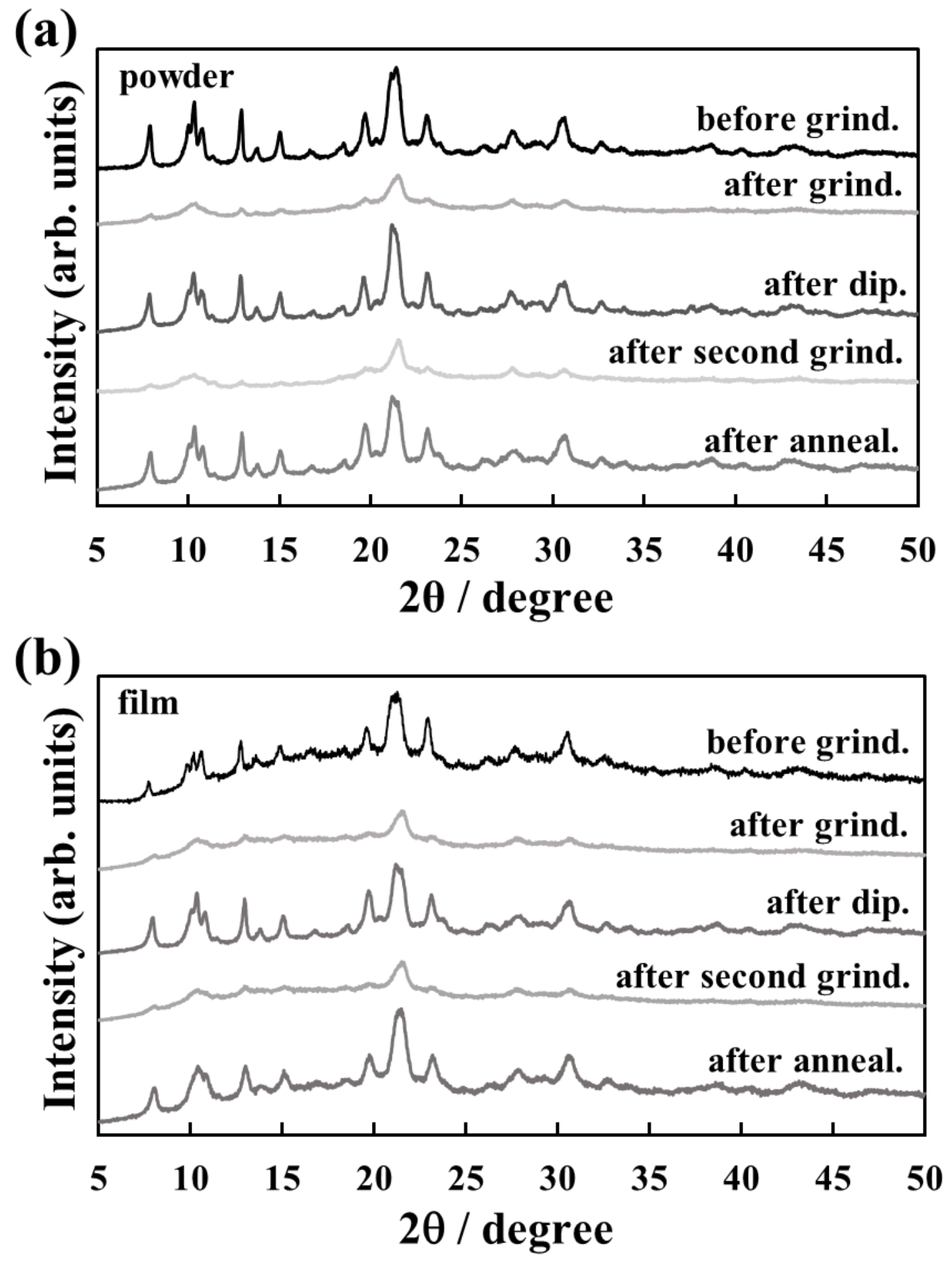

Fig. 9 

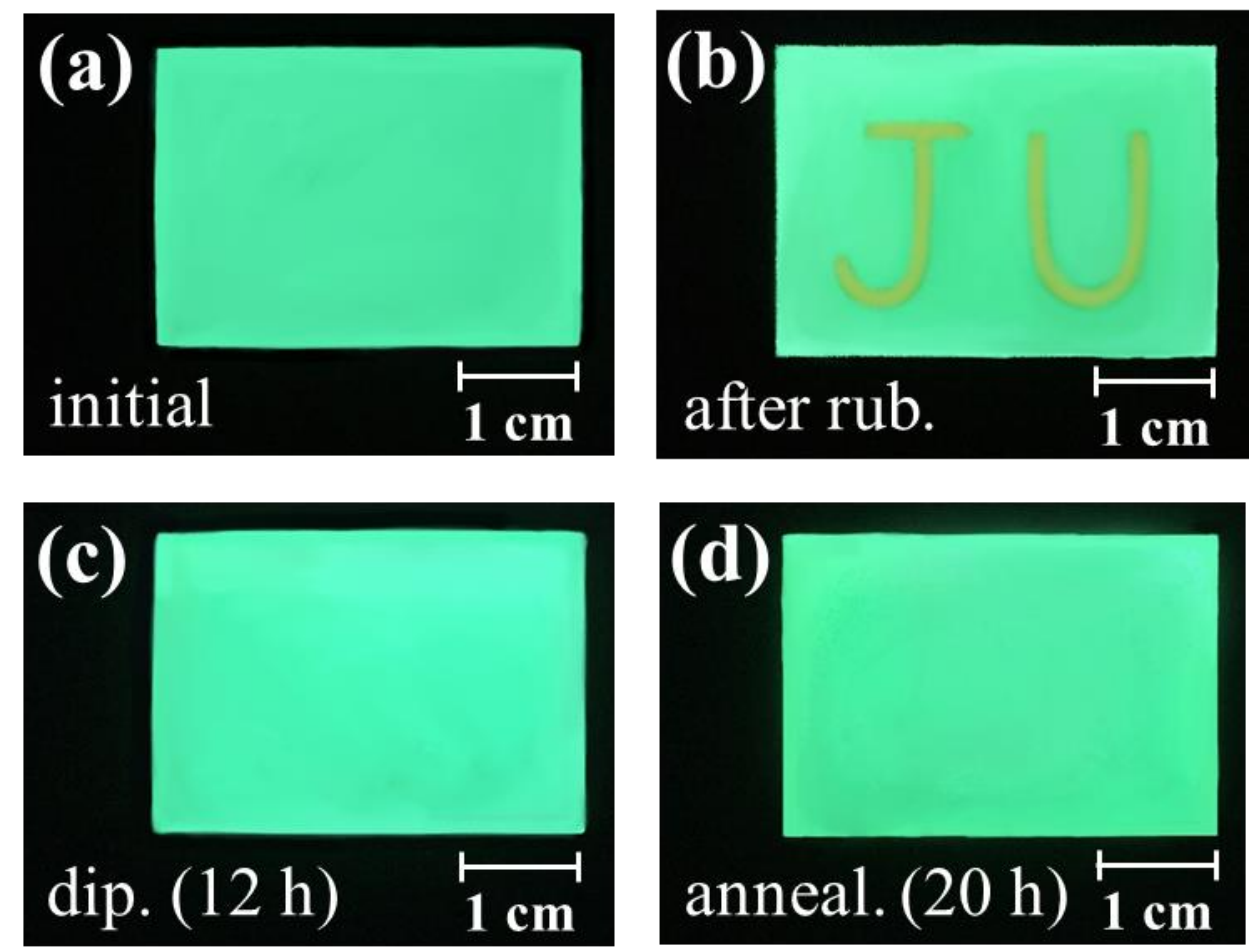

Fig. 10

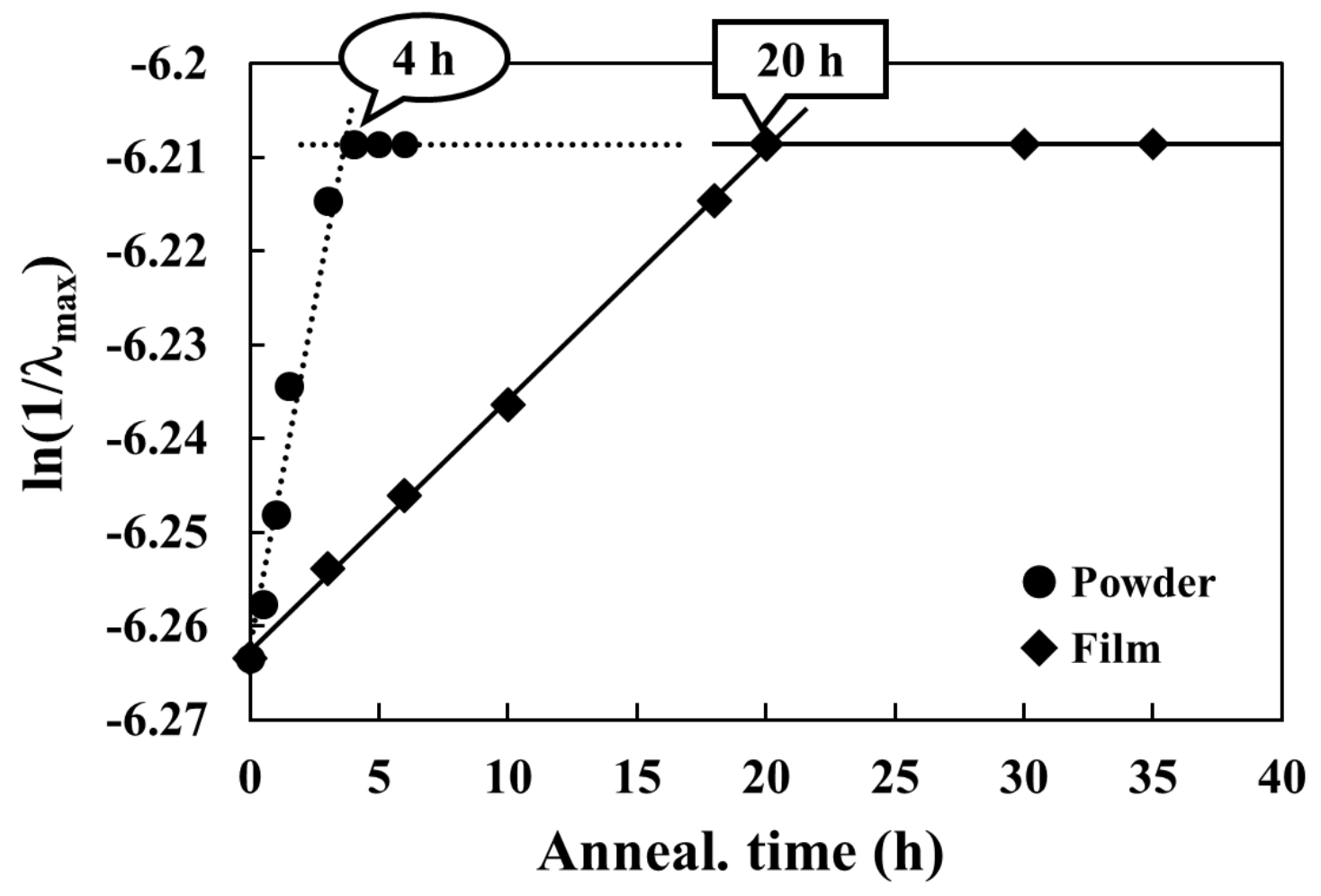

Fig. 11 